\title{
Variability in the Number of Fish Taken by Larva Nets*
}

\author{
Hitoshi IDA** \\ (Received May1, 1972)
}

\begin{abstract}
The present study's objective has been to clarify the tow to tow variations in the number of fish larvae taken in relation to the variation of the volume of water filtered. More than 230 surface towings and $\mathbf{1 7 0}$ towings of subsurface layers were carried out in the regions off central and southern Japan, and the results obtained are as follows:

(1) Volume of water filtered vary from tow to tow, net to net and it is difficult to keep the volume of water filtered to a constant level by only maintaining a constant ship speed and towing time.

(2) Collecting efficiency both in number and size appeared better in small meshed nets than large meshed nets at sea areas of poor plankton. However, the difference in the numbers collected diminished at towings in rich plankton waters, and the variation in collection became large with small meshed nets.

(3) Variations in collection was large for samples of low collection and this decreased by increasing the amount of collection in numbers.

(4) Movement of net during towing was stable at shallow layers and at calm seas and it oscillated to some extent at deeper layers and seas having complexed water stratification.
\end{abstract}

The distribution of planktonic animals has been studied by many workers using many kinds of plankton nets and by changing the towing methods. However, the number of fish taken by these nets may be affected by the type of net, mesh size, towing conditions and the behavior of the organisms. From the view point of technical problems, towing characteristics such as net movements in water ${ }^{1,2)}$ filtration mechanisms $^{3-7)}$, and mesh selectivity or efficiency of sampling ${ }^{8)}$ have been fairly clarified. The distribution of the number of organisms $^{9-13)}$ and net avoidance ${ }^{14-16)}$ have also been analyzed by many authors. However, these factors are rather complicated, e.g. size of net determines the total mesh opening and towing speed is related to filtration efficiency, net avoidance and net clogging. Comparing the efficiencies of different sampling nets, the results are not always in accordance with other authors, e.g. some authors report smaller net catches less than the expected from the mouth opening ${ }^{10,10}$ or the efficiency of a smaller sampler is not inferior to that of a larger ${ }^{8)}$. Recently, the importance of total mesh opening of net in filtration have been reported ${ }^{18,19)}$. So for a comparison of data obtained from different nets, the relative amounts of net samples to the filtering area must be taken into consideration.

Furthermore, most of the reports show confidence limits of the mean number of organisms $\operatorname{taken}^{9-17)}$ and the results are almost in accord with the "half or double rule"

* A part of the doctoral thesis of the author carried out under the guidance of former Professor Y. Hryama.

** Fisheries Department, University Museum, the University of Tokyo, Tokyo, Japan. 
of SILLIMAN ${ }^{17)}$. Adding to these, the inadequacy of the use of a net made of different mesh sizes for quantitative analysis is indicated ${ }^{20,21)}$.

And most of these studies have been done with small sized and fine meshed plankton nets, especially in vertical towing. And little has been known about the sampling variation using larger sized and coarse meshed nets, especially for variations in the number of fish larvae taken by horizontal towing. The present study has aimed to clarify tow to tow variation in the number of fish taken in relation to the variation of water volume filtered and also to the size composition of fish.

\section{Methods}

Sampling method: All data were collected during the years of 1965 to 1967 by towing of larva nets carried out aboard the Tansei Maru, 257 tons, a research vessel of the Ocean Research Institute of the University of Tokyo. Most of the cruises were undertaken in the central part of Sagami Bay and off the sea of southern Japan as shown in Fig. 1.

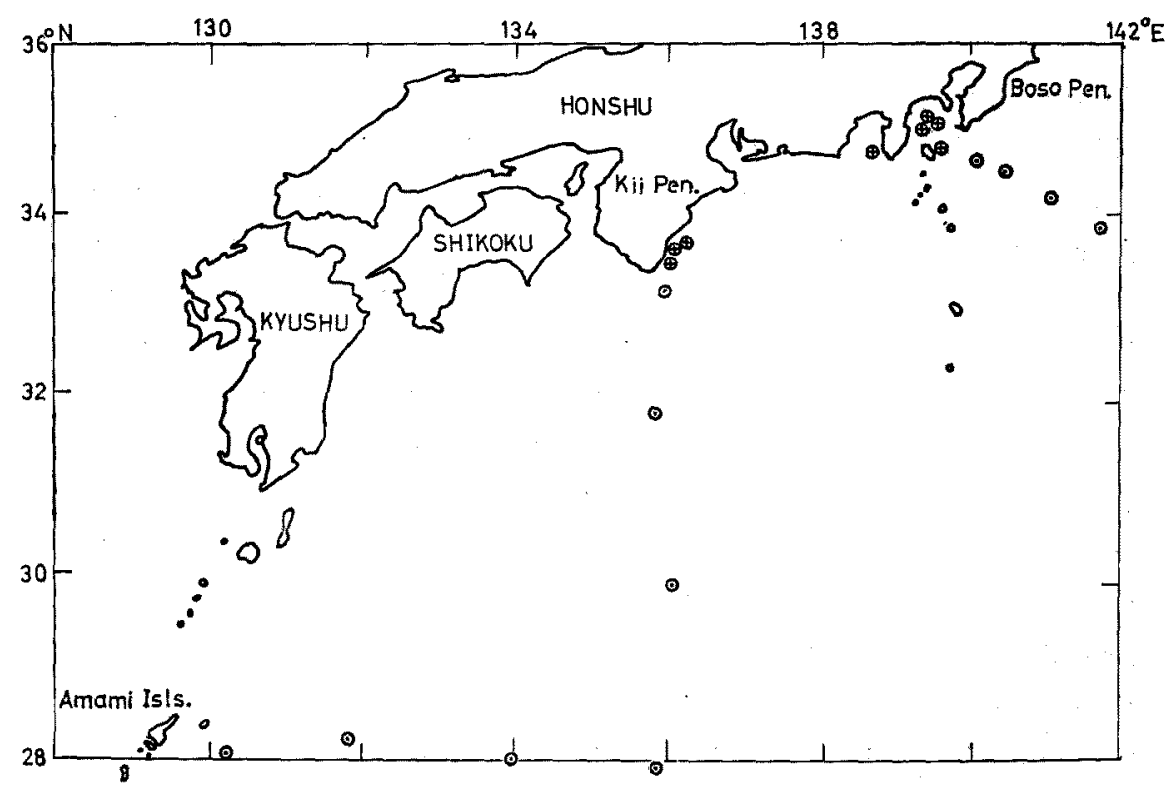

Fig. 1. Site of collection. Each mark shows the following survey:

$\bigcirc:$ two to three double surface towings and an oblique tow at high sea area

$\oplus$ : stratified towings from surface to $100 \mathrm{~m}$ deep at coastal area.

Nets used were cylindrical-conical type which were made by procedures recommended by the National Academy of Sciences of U.S.A. ${ }^{20)}$. At most of the stations, only surface towings and oblique towings were made using 1.0 and $0.5 \mathrm{~mm}$ meshed larva 

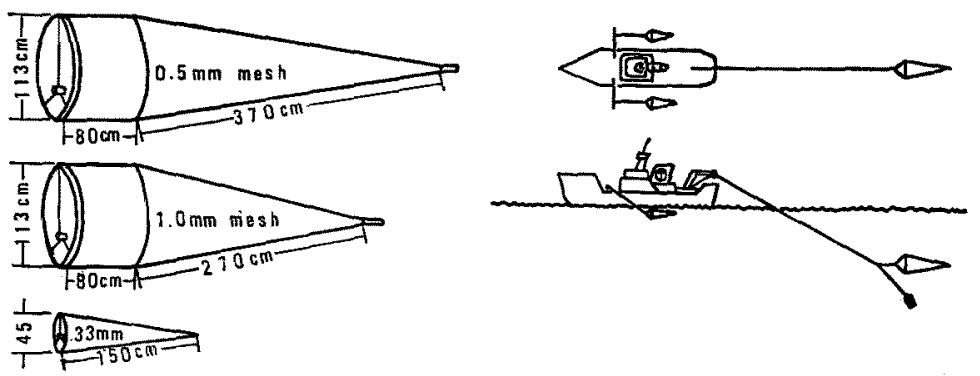

Fig. 2. Nets used for survey and schematic representation of towing method.

nets. Stratified towings were undertaken in Sagami Bay and Kumano Nada. No opening and closing apparatus was used.

Towing speeds were kept at two knots per hour* during the survey for both horizontal and oblique towings.

The volume of water filtered was estimated with Tsurumi-Seiki type flow meter. At the beginning of each cruise the flow meters were towed vertically from a depth of $100 \mathrm{~m}$ without net at a speed of one meter per second (two knots per hour) for several times. The rotation characteristics were expressed as the mean number of rotations per unit distance. Then, at the end of towing, actual measurements were adjusted by each flow meter characteristic. The rotation characteristics of the flow meters are shown in Table 1.

Table 1. Rotative characteristics of the six flow meters used.

\begin{tabular}{crcc}
$\begin{array}{c}\text { flow meter } \\
\text { number }\end{array}$ & $\begin{array}{c}\text { Rotation } \\
\text { per } 100 \mathrm{~m}\end{array}$ & $\begin{array}{c}\text { mean } \\
\text { rotation }\end{array}$ & $\begin{array}{c}\text { Variation of } \\
\text { rotation } / 100 \mathrm{~m}\end{array}$ \\
\hline No. 668 & $1150-1200$ & 1186 & 4 \\
No. 682 & $1090-1185$ & 1128 & 40 \\
No. 671 & $910-1050$ & 958 & 46 \\
No. 672 & $1105-1190$ & 1130 & 28 \\
No. 674 & $935-1065$ & 998 & 39 \\
No. 676 & $1110-1175$ & 1119 & 19 \\
\hline
\end{tabular}

Processing: At the end of each towing the organisms taken were transferred to a bucket by washing the net, and then preserved in $10 \%$ formalin. Each sample was divided into two to eight equal volume of sub-samples according to the amount of organisms taken. From these sub-samples fish larvae and eggs were sorted.

Analysis of data: In order to know the variability of volume of water filtered and the number of fish larvae taken, method of the analysis of variance was applied. The

* Ship speed was indicated by a pressure sensitive apparatus principally designed for ordinary cruising speeds. It showed lower values than the actual ship speed at slow cruising due to the effect of air bubbles. On some occasions, the difference between meter readings of the vessel and the actual distance run attained $30 \%$ or a little more. 

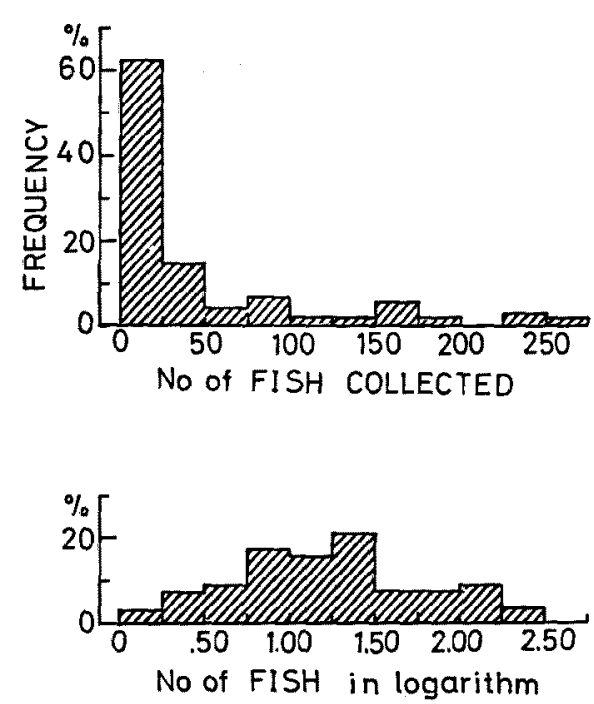

Fig. 3. Distribution of collection of larval fish from surface towings in June, 1966. Net used was $113 \mathrm{~cm}$ diameter, $0.5 \mathrm{~mm}$ meshed net. abundance of fish larvae taken was expressed as number of larvae per 1000 cubic meters of water and these values were then transformed to logarithmic values in order to remove skewness in the frequency distribution of collection (Fig. 3). The following factors are considered; Station (S), Net $(\mathrm{N})$ and Tow $(\mathrm{T})$. The stations which are in the order of operations were decided principally by the course of the vessel, though there might be the possibility of closer relations in the biological conditions between every neighboring two stations than widely separated stations, so (S) has random effects. (N) has fixed treatment effects because the difference between effect of nets is expected to clarify. The first towing affects

upon the following towing e.g. net clogging by the first tow will cause a decrease of filtration and collection to the subsequent tow. Thus the order of tow must be discriminated, so $(T)$ is treated as a fixed effect factor.

Then the following scheme can be set up,

$$
x_{i j k}=\mu+a_{i}+b_{j}+c_{k}+(a b)_{i j}+(a c)_{i k}+(b c)_{j k}+e_{i j k}
$$

where $x$ : the number of fish expressed as logarithmic value

$\mu:$ grand mean

$a$ : the effect of net kind on collection $(1,2)$

$b$ : the effect of towing $(1,2)$

$e:$ the effect of experimental error

It must be noted here that the mean of the effects of net $(\bar{a})$ and towing $(\bar{b})$ and

Table 2. Analysis of variance.

\begin{tabular}{lcl}
\hline $\begin{array}{c}\text { Source of } \\
\text { variation }\end{array}$ & \multicolumn{1}{c}{$\begin{array}{c}\text { Degree of } \\
\text { freedom }\end{array}$} & \multicolumn{1}{c}{ Expected variances } \\
\hline Net $(\mathrm{N})$ & $l-1$ & $m n \sigma^{2} N+m \sigma^{2} N \times S+\sigma^{2} E$ \\
Tow (T) & $m-1$ & $l n \sigma^{2} T+l \sigma^{2} T \times S+\sigma^{2} E$ \\
Station $(\mathrm{S})$ & $n-1$ & $l m \sigma^{2} S+m \sigma^{2} N \times S+l \sigma^{2} r \times S+\sigma^{2} E$ \\
$\mathrm{~N} \times \mathrm{T}$ & $(l-1)(\mathrm{m}-l)$ & $n \sigma^{2} N \times T+\sigma^{2} E$ \\
$\mathrm{~N} \times \mathrm{S}$ & $(l-1)(n-1)$ & $m \sigma^{2} N \times S+\sigma^{2} E$ \\
$\mathrm{~T} \times \mathrm{S}$ & $(m-1)(n-1)$ & $l \sigma^{2} T \times S+\sigma^{2} E$ \\
Error & $(l-1)(m-1)(n-1)$ & $\sigma^{2} E$ \\
\hline
\end{tabular}


interaction of these factors $(\overline{a b})$ are reduced to zero but $(\bar{c}),(\overline{a c})$ and $(\overline{b c})$ can not be reduced to zero. Then the following analysis of variance can be used (Table 2).

In the preliminary survey it was observed that the same tendency between variation in the number of fish larvae taken and the volume of water filtered in larva net towing existed, so the same model has been used for the analysis of variation of volume of water filtered. In this case $x$ is the volume of water in 1000 cubic meters and $a$ is the effect of net kind for filtration.

\section{Results}

Variability of water volume filtered: In order to get information on the variation of volume of water filtered, the upper two types of net as shown in Fig. 2 were towed in both high sea area (poor plankton area) and coastal area (rich plankton area). The differences in the volume of water filtered between the 1st and the 2 nd towings and also between $0.5 \mathrm{~mm}$ and $1.0 \mathrm{~mm}$ meshed nets were tested. At each station both types of larva net were towed simultaneously at both starboard and port of the ship for 20 minutes and this paired tow was repeated. During towing the upper-most part of the mouth ring of the net was kept at the level of water surface. The settled volume of plankton for 24 hours, excepting large organisms such as jellyfishes, taken by the two types of net are as follows:

$\begin{array}{ll}\text { high sea area } & 21-169 \mathrm{cc} / 1000 \mathrm{~m}^{3} \text { (mean } 106 \mathrm{cc} \text { for } 1.0 \mathrm{~mm} \text { meshed net) } \\ \begin{array}{l}\text { (10-14th, } \\ \text { June, 1966) }\end{array} & 119-399 \mathrm{cc} / 1000 \mathrm{~m}^{3} \text {, (mean } 231 \mathrm{cc} \text { for } 0.5 \mathrm{~mm} \text { meshed net) } \\ \text { coastal area } & 147-1259 \mathrm{cc} / 1000 \mathrm{~m}^{3} \text {, (mean } 439 \mathrm{cc} \text { for } 1.0 \mathrm{~mm} \text { meshed net) } \\ \begin{array}{l}\text { (12, 13th, } \\ \text { April, 1967) }\end{array} & 223-2202 \mathrm{cc} / 1000 \mathrm{~m}^{3}, \text { (mean } 603 \mathrm{cc} \text { for } 0.5 \mathrm{~mm} \text { meshed net) }\end{array}$

The results of these operations are shown in Figs. 4 and 5 and the results of analysis of variances are shown in Table 3 and 4 . As can be seen in the tables, differences between nets is very large at high sea area, which mean that the filtration of coarse meshed net is larger than the fine meshed one. On the contrary, in coastal areas, large difference is not observed however, some differences seem to be present between order of towings, which means that the difference of the volume of water filtered is more affected by mesh clogging than differences in mesh size. Among interactions, $\mathrm{N} \times \mathrm{T}$ (interaction between net and tow) is usually negligible and small but $\mathrm{N} \times \mathrm{S}$ is significant. The results of other factors are not clear and many factors are confounding.

Variability of the number of fish larvae taken: In order to know the variation of the number of larval fish taken, data obtained from replicate towings with $0.5 \mathrm{~mm}$ and $1.0 \mathrm{~mm}$ meshed nets were analyzed. All the larvae were taken by the towings men- 


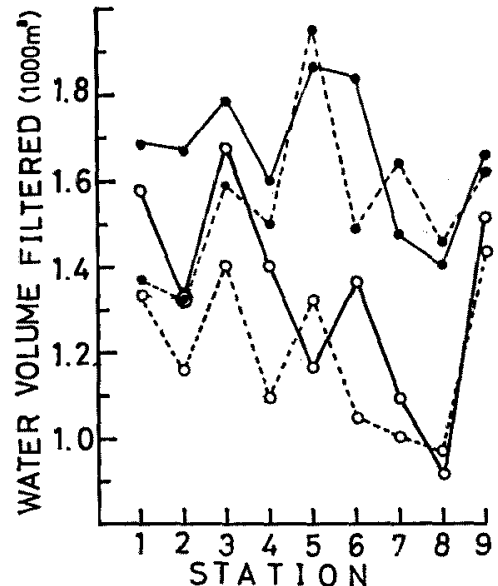

Fig. 4. Variation of volume of water filtered by different net and by tow order. Operations were carried out at high sea area, June, 1966.

$0.5 \mathrm{~mm}$ meched net, first tow

_ - 0 - - $0.5 \mathrm{~mm}$ meshed net, second two

$\longrightarrow 1.0 \mathrm{~mm}$ meshed net, first tow

_. $1.0 \mathrm{~mm}$ meshed net, second tow

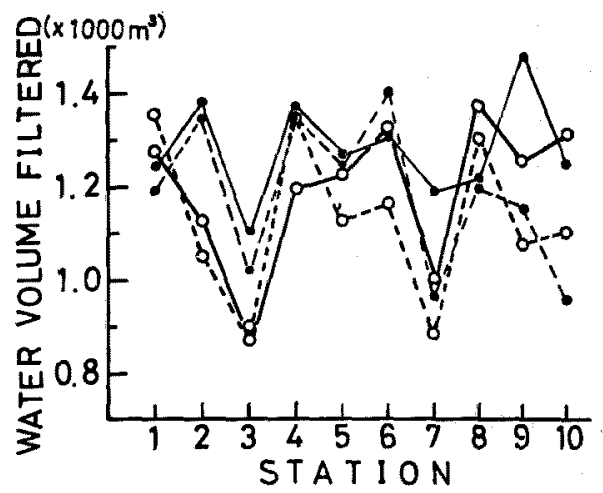

Fig. 5. Variation of volume of water filtered by different net and by two order. Operations were carried out at coastal area, April, 1967.

$-0.5 \mathrm{~mm}$ meshed net, first tow

- - $\mathrm{O}---0.5 \mathrm{~mm}$ meshed net, second tow

$1.0 \mathrm{~mm}$ meshed net, first tow

- . $1.0 \mathrm{~mm}$ meshed net, second tow

Table 3. Analysis of variance: variations in the volume of water filtered by different nets and by order of two at high sea areas.

\begin{tabular}{lrccccc}
\hline $\begin{array}{l}\text { Source of } \\
\text { variation }\end{array}$ & $\begin{array}{c}\text { Sum of } \\
\text { square }\end{array}$ & $\begin{array}{c}\text { Degree of } \\
\text { freedom }\end{array}$ & $\begin{array}{c}\text { Mean } \\
\text { square }\end{array}$ & F & F.05 & F.01 \\
\hline Total & 2.4149 & 35 & & & & \\
Net & .9604 & 1 & .9604 & $23.59^{* *}$ & 5.32 & 11.26 \\
Tow & .1394 & 1 & .1394 & 4.12 & 5.32 & 11.26 \\
Station & .6790 & 8 & .0849 & - & & \\
Net $\times$ St. & .3253 & 8 & .0407 & $8.28^{* *}$ & 3.44 & 6.03 \\
Tow $\times$ St. & .2702 & 8 & .0338 & $6.88^{* *}$ & 3.44 & 6.03 \\
Net $\times$ Tow & .0013 & 1 & .0013 & $<1$ & & \\
Error & .0393 & 8 & .0049 & & & \\
\hline
\end{tabular}

Table 4. Analysis of variance: variations in the volume of water filtered by different nets and by order of two at coastal area.

\begin{tabular}{lcccccc}
\hline $\begin{array}{l}\text { Source of } \\
\text { variation }\end{array}$ & $\begin{array}{c}\text { Sum of } \\
\text { square }\end{array}$ & $\begin{array}{c}\text { Degree of } \\
\text { freedom }\end{array}$ & $\begin{array}{c}\text { Mean } \\
\text { square }\end{array}$ & F & F.05 & F.01 \\
\hline Total & .9687 & 39 & & & & \\
Net & .0337 & 1 & .0337 & 1.73 & 5.12 & 10.56 \\
Tow & .0548 & 1 & .0548 & 4.72 & 5.12 & 10.56 \\
Station & .5494 & 9 & .0610 & - & & 5.18 \\
Net $\times$ St. & .1751 & 9 & .0195 & $3.70^{*}$ & 3.35 \\
Tow $\times$ St. & .1044 & 9 & .0116 & 2.23 & 3.18 & 5.35 \\
Net $\times$ Tow & .0039 & 1 & .0039 & $<1$ & & \\
Error & .0474 & 9 & .0052 & & & \\
\hline
\end{tabular}




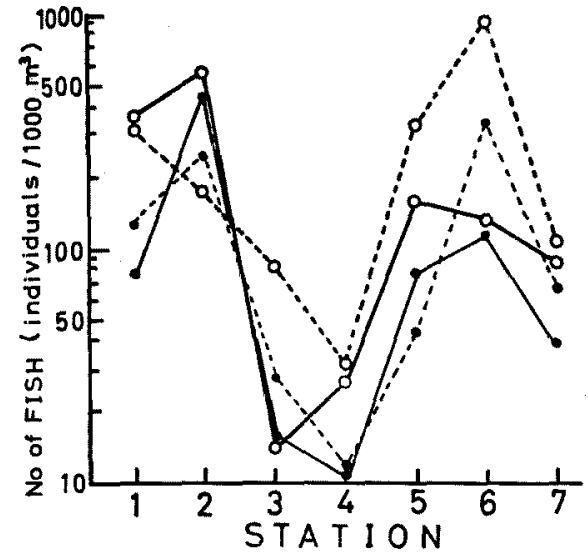

Fig. 6. Variation of catches of larval fish from two nets in paired tow. Operations were carried out at high sea area, June, 1966.

$0.5 \mathrm{~mm}$ meshed net, first tow

- $-0--0.5 \mathrm{~mm}$ meshed net, second tow

$1.0 \mathrm{~mm}$ meshed net, first two

$1.0 \mathrm{~mm}$ meshed net, second tow

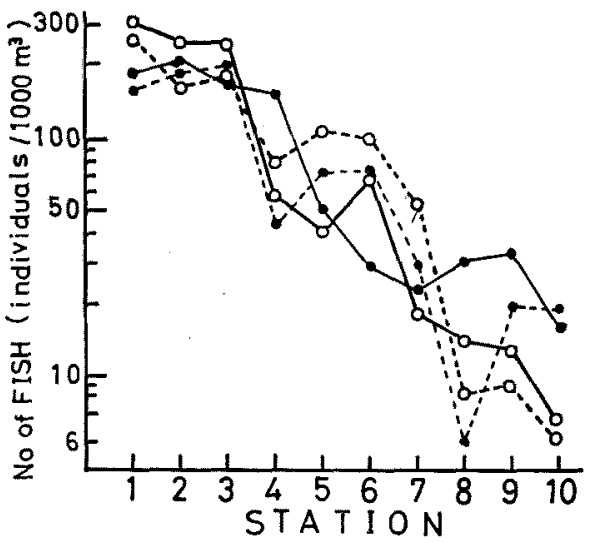

Fig. 7. Variation of catches of larval fish by two nets in paired tow. Operations were carried out at coastal area, April, 1967.

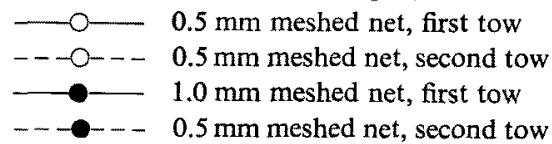

Table 5. Analysis of variance: variations in the collection of larval fish by different nets and by order of tow at high sea area.

\begin{tabular}{|c|c|c|c|c|c|c|}
\hline $\begin{array}{l}\text { Source of } \\
\text { variation }\end{array}$ & $\begin{array}{l}\text { Sum of } \\
\text { square }\end{array}$ & $\begin{array}{l}\text { Degree of } \\
\text { freedom }\end{array}$ & $\begin{array}{l}\text { Mean } \\
\text { square }\end{array}$ & $F$ & $F_{.05}$ & $F_{.01}$ \\
\hline Total & 7.7763 & 27 & & & & \\
\hline Net & .7394 & 1 & .7394 & $14.30^{* *}$ & 5.99 & 13.74 \\
\hline Tow & .2006 & 1 & .2006 & 1.71 & 5.99 & 13.74 \\
\hline Station & 5.6043 & 6 & .9341 & - & & \\
\hline Net $\times$ St. & 3079 & 6 & .0517 & 1.67 & 4.28 & 8.47 \\
\hline Tow $\times$ St. & .7026 & 6 & .1171 & 3.78 & 4.28 & 8.47 \\
\hline Net $\times$ Tow & .0258 & 1 & .0258 & $<1$ & & \\
\hline Error & .1857 & 6 & .0309 & & & \\
\hline
\end{tabular}

Table 6. Analysis of variance: variations in the collection of larval fish by different nets and by order of tow at coastal area.

\begin{tabular}{lrrrrrr}
\hline $\begin{array}{l}\text { Source of } \\
\text { variation }\end{array}$ & $\begin{array}{c}\text { Sum of } \\
\text { square }\end{array}$ & $\begin{array}{c}\text { Degree of } \\
\text { freedom }\end{array}$ & $\begin{array}{c}\text { Mean } \\
\text { square }\end{array}$ & F & F.05 & F.01 \\
\hline Total & 10.7732 & 39 & & & & \\
Net & .0525 & 1 & .0525 & 1.09 & 5.12 & 10.56 \\
Tow & .0030 & 1 & .0030 & $<1$ & & \\
Station & 9.4570 & 9 & 1.0508 & -1.15 & 3.18 & 5.35 \\
Net $\times$ St. & .4332 & 9 & .0481 & 2.18 & 5.35 \\
Tow $\times$ St. & .6063 & 9 & .0674 & 3.01 & 3.18 & \\
Net $\times$ Tow & .0199 & 1 & .0199 & $<1$ & & \\
Error & .2013 & 9 & .0224 & & &
\end{tabular}


tioned in the previous section. The results are shown in Figs. 6 and 7 and the results of analysis of variances are shown in Table 5 and 6 . As it can be expected, the value of mean square for stations is large. It shows the heterogeneity of populations of larvae among stations. It must be noted here that a significant difference is observed only in between mesh size of net at high sea area i.e. the mesh differential is definite at high sea area. However, in coastal area, the difference in collecting efficiency between $0.5 \mathrm{~mm}$ and $1.0 \mathrm{~mm}$ meshed net is not significant.

Mesh selectivity: The number and the size composition of three species viz. Thunnus thynnus, Trachurus japonicus and Engraulis japonica taken by $1.0 \mathrm{~mm}$ and $0.5 \mathrm{~mm}$ meshed nets were compared. Nets were towed simultaneously on both sides of the ship and each surface towing was repeated twice or three times at each station.

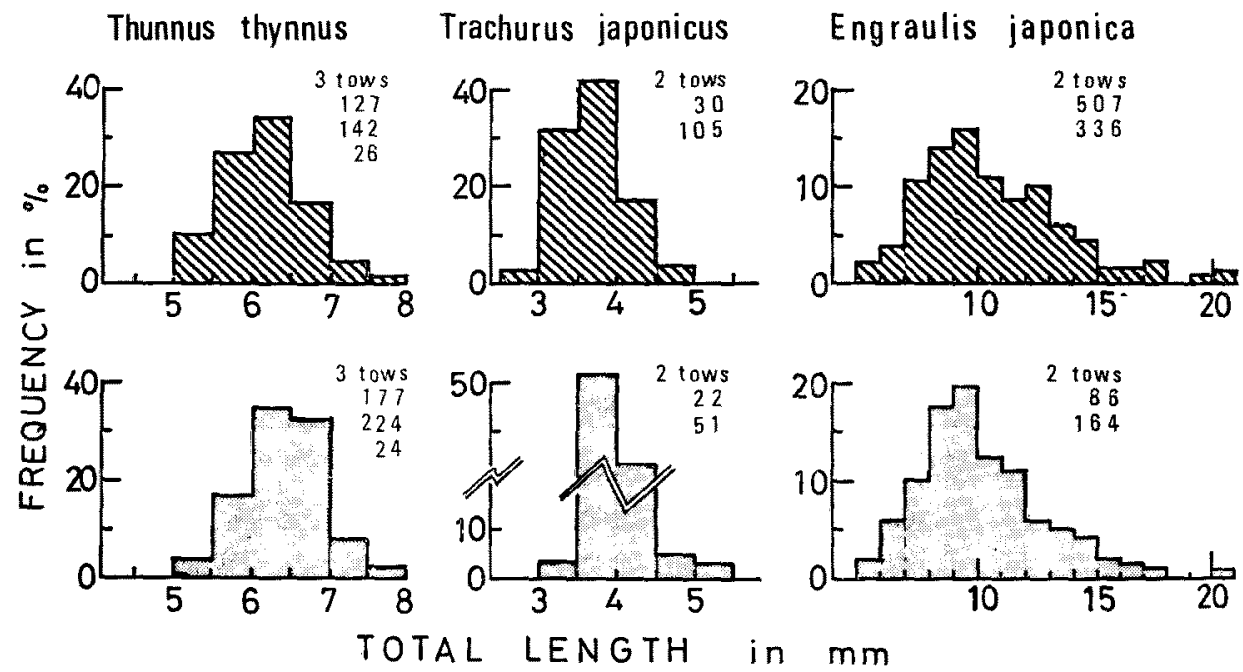

Fig. 8. Difference in size composition and number of larvae taken from two nets. The upper three figures show the collection from $0.5 \mathrm{~mm}$ meshed net and the lowers show that from $1.0 \mathrm{~mm}$ meshed net. Figures are showing the number of fish taken per each tow of 1000 cubic meters of water.

The sampling site and data for each species is as follows; $T$. thynnus: $28^{\circ} 20^{\prime} \mathrm{N}, 131^{\circ} 51^{\prime} \mathrm{E}$, June 10,1966 , midnight; $T$. japonicus: $31^{\circ} 51^{\prime} \mathrm{N}, 135^{\circ} 55^{\prime} \mathrm{E}$, June 14,1966 , morning; $E$. japonica: $35^{\circ} 10^{\prime} \mathrm{N}, 139^{\circ} 29^{\prime} \mathrm{E}$, July 1, 1966, early morning. The results are shown in Fig. 8. As can be seen in the figure, the coarse net collected less number of smaller size group and statistical differences are found in the size composition of $T$. thynnus and $T$. japonicus. However, the number of fish larvae collected by these nets does not differ constantly i.e. larger collections were recorded by the fine meshed net in the cases of $T$. japonicus and E. japonica, while in the case of $T$. thynnus collected by the coarse meshed net was larger than that by the fine meshed one. And the differences are signi- 
ficant in both cases.

Relationship between the amount and its variation in the number of fish taken: To get information on adequate sampling duration or adequate sampling size in number, relationship between the degree of sampling error and the amount of fish taken was studied. The amount of fish larvae taken was classified into three classes by the number of fish taken per unit volume of water filtered. Operations were carried out in Kumano Nada and Sagami Bay, using larva nets (113 cm diameter, $4.5 \mathrm{~m}$ long, $0.5 \mathrm{~mm}$ mesh) and NORPAC nets ( $45 \mathrm{~cm}$ diameter, $150 \mathrm{~cm}$ long, $0.33 \mathrm{~mm}$ mesh) as shown in Fig. 2. NORPAC nets were towed horizontally at $20 \mathrm{~m}$ depth for collecting smaller individuals and the larva net was used for surface towings. The results are shown in Table 7 . The two factors, Tow and Station are considered. In this case all expected values of mean square of error term include both error and interaction component i.e. $\sigma_{\text {error }}^{2}$ and

Table 7. Number of fish larvae in paired samples classified by the amount of collection. Figures are expressed as number of fish larvae per $100 \mathrm{~m}^{3}$ of water for NORPAC net and number of larvae per $1000 \mathrm{~m}^{3}$ for larva net.

NORPAC net ( $20 \mathrm{~m}$ depth, horizontal tow)

\begin{tabular}{|c|c|c|c|c|c|c|c|c|}
\hline \multicolumn{3}{|c|}{ Range of the mean $13-49$} & \multicolumn{3}{|c|}{$51-168$} & \multicolumn{3}{|c|}{$204-656$} \\
\hline Station & A sample & B sample & St. & A sample & B sample & St. & A sample & B sample \\
\hline 1 & 14 & 11 & 1 & 64 & 38 & 1 & 184 & 224 \\
\hline 2 & 14 & 14 & 2 & 55 & 49 & 2 & 234 & 223 \\
\hline 3 & 15 & 14 & 3 & 72 & 56 & 3 & 265 & 332 \\
\hline 4 & 11 & 21 & 4 & 62 & 74 & 4 & 423 & 350 \\
\hline 5 & 18 & 16 & 5 & 87 & 61 & 5 & 524 & 477 \\
\hline 6 & 19 & 24 & 6 & 101 & 104 & 6 & 524 & 565 \\
\hline 7 & 44 & 20 & 7 & 96 & 115 & 7 & 523 & 615 \\
\hline 8 & 53 & 29 & 8 & 150 & 124 & 8 & 545 & 607 \\
\hline 9 & 57 & 32 & 9 & 148 & 148 & 9 & 839 & 506 \\
\hline \multirow[t]{3}{*}{10} & 44 & 54 & 10 & 161 & 134 & & & \\
\hline & & & 11 & 160 & 172 & & & \\
\hline & & & 12 & 192 & 144 & & & \\
\hline \multicolumn{9}{|c|}{ Larva net (surface tow) } \\
\hline \multicolumn{2}{|c|}{ Range of the mean } & n $7-18$ & \multicolumn{3}{|c|}{$24-98$} & \multicolumn{3}{|c|}{$102-761$} \\
\hline Station & A sample & B sample & St. & A sample & B sample & St. & A sample & B sample \\
\hline 1 & 7 & 6 & 1 & 24 & 23 & 1 & 108 & 95 \\
\hline 2 & 14 & 6 & 2 & 32 & 17 & 2 & 140 & 141 \\
\hline 3 & 9 & 12 & 3 & 29 & 20 & 3 & 330 & 162 \\
\hline 4 & 13 & 10 & 4 & 22 & 52 & 4 & 168 & 158 \\
\hline 5 & 11 & 13 & 5 & 40 & 27 & 5 & 279 & 227 \\
\hline 6 & 13 & 8 & 6 & 53 & 22 & 6 & 375 & 367 \\
\hline 7 & 13 & 9 & 7 & 55 & 38 & 7 & 392 & 382 \\
\hline 8 & 12 & 9 & 8 & 57 & 47 & 8 & 375 & 427 \\
\hline \multirow[t]{3}{*}{9} & 24 & 11 & 9 & 62 & 49 & 9 & 448 & 404 \\
\hline & & & 10 & 82 & 104 & 10 & 552 & 561 \\
\hline & & & & & & 11 & 869 & 652 \\
\hline
\end{tabular}


Table 8. Analysis of variance: relationship between amount and variation in collection.

\section{NORPAC net}

Range of collection: less than 50

Range: $51-200$

Range: more than 201

\begin{tabular}{|c|c|c|c|c|c|c|c|c|c|c|c|c|}
\hline $\begin{array}{l}\text { Source of } \\
\text { variation }\end{array}$ & $\begin{array}{l}\text { Sum of } \\
\text { square }\end{array}$ & $\begin{array}{l}\text { Degree } \\
\text { of } \\
\text { freedom }\end{array}$ & $\begin{array}{l}\text { Mean } \\
\text { square }\end{array}$ & F & S. s. & D. f. & M. s. & $\mathrm{F}$ & S. s. & D. f. & M. s. & $\mathbf{F}$ \\
\hline Station & .8925 & 9 & .0992 & & .8583 & 11 & .0780 & & .5660 & 8 & .0707 & \\
\hline Tow & .0727 & 1 & .0727 & $6.32^{*}$ & .0160 & 1 & .0160 & 3.48 & .0072 & 1 & .0072 & 1.64 \\
\hline Error & .1037 & 9 & .0115 & & .0509 & 11 & .0046 & & .0348 & 8 & .0044 & \\
\hline & \multicolumn{4}{|c|}{$\begin{aligned} \sigma & =.105 \\
\sigma t & =.078 \\
\sigma^{3}+\sigma_{t}^{2} & =.133\end{aligned}$} & \multicolumn{4}{|c|}{$\begin{aligned} \sigma & =.068 \\
\sigma_{t} & =.031 \\
\sigma_{t}^{2} & =.075\end{aligned}$} & \multicolumn{4}{|c|}{$\begin{aligned} \sigma & =.066 \\
\sigma_{t} & =.017 \\
+\sigma^{2} & =069\end{aligned}$} \\
\hline
\end{tabular}

\section{LARVA net}

\begin{tabular}{|c|c|c|c|c|c|c|c|c|c|c|c|c|}
\hline \multirow{2}{*}{ 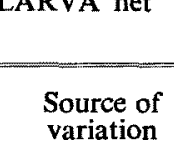 } & \multicolumn{4}{|c|}{ Range of collection: less than 20} & \multicolumn{4}{|c|}{ Rang: $21-100$} & \multicolumn{4}{|c|}{ Range: more than 101} \\
\hline & $\begin{array}{l}\text { Sum of } \\
\text { square }\end{array}$ & $\begin{array}{l}\text { Degree } \\
\text { of } \\
\text { freedom }\end{array}$ & $\begin{array}{l}\text { Mean } \\
\text { square }\end{array}$ & $\mathbf{F}$ & S. s. & D. f. & M. s. & F & S.s. & D. f. & M.s. & $\mathbf{F}$ \\
\hline Station & .1943 & 8 & .0243 & & .6683 & 9 & .0743 & & 1.4115 & 10 & .1412 & \\
\hline Tow & .1089 & 1 & .1089 & $5.79^{*}$ & .0650 & 1 & .0650 & $6.25^{*}$ & .0169 & 1 & .0169 & 3.45 \\
\hline Error & .1501 & 8 & .0188 & & .0938 & 9 & .0104 & & .0485 & 10 & .0049 & \\
\hline & \multicolumn{4}{|c|}{$\begin{aligned} \sigma & =.137 \\
\sigma_{t} & =.100\end{aligned}$} & \multicolumn{4}{|c|}{$\begin{aligned} \sigma & =.102 \\
\sigma_{\ell} & =.074\end{aligned}$} & \multicolumn{4}{|c|}{$\begin{aligned} \sigma & =.070 \\
\sigma t & =.033\end{aligned}$} \\
\hline
\end{tabular}




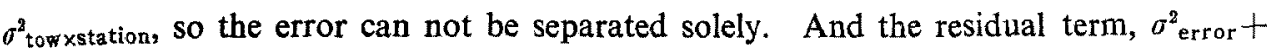
$\sigma_{\text {stxtow }}^{2}$, represents error. The results of analysis of variance are shown in Table 8 . It is evident from this table that all of these values become smaller with the increase of the mean, showing the fact the more number of fish taken the less difference is there especially between Tows. And tow variation $\sigma_{t}$ is generally smaller than that of the experimental error $\sigma$. And it must be noted here that the $F$ values show significant difference in the case of a lesser number than 50 individuals per $100 \mathrm{~m}^{3}$ for NORPAC net and less than 100 individuals per $1000 \mathrm{~m}^{3}$ for larva net. This means that the difference in the catch between right and left nets (in NORPAC nets) or between the 1st and the 2nd towings (in larva net) is significant in the case of small amount of collection.

Net movement and volume of water filtered at different towing depth: Towing record was analyzed to study the relative volume of water filtered in descent and in ascent of net that is referred as contaminant for the water volume filtered at the designated towing layers. The results obtained using Alzawa's method ${ }^{2 y}$ is shown in Table 9. The towing method is represented in Fig. 2. The wire was run out and retrieved at the speed of $1 \mathrm{~m} / \mathrm{sec}$. Net was towed for 20 minutes for just after the wire was run out. It is evident that more than one quarter of water volume was filtered in descent and in ascent comparing with that in designated layers in the cases of deeper towings than $30 \mathrm{~m}$ depth. As it was expected, this contamination occured less in descent than that in ascent.

Table 9. Relation of volume of water filtered at towing layers and that in descent and in ascent.

\begin{tabular}{cccccc}
\hline $\begin{array}{c}\text { Purposed } \\
\text { layers }\end{array}$ & $\begin{array}{c}\text { No. of } \\
\text { tows }\end{array}$ & $\begin{array}{c}\text { Contaminant } \\
\text { in descent }\end{array}$ & $\begin{array}{c}\text { Purposed } \\
\text { layers }\end{array}$ & $\begin{array}{c}\text { Contaminant } \\
\text { in ascent }\end{array}$ & $\begin{array}{c}\text { Total of } \\
\text { contaminant }\end{array}$ \\
\hline $10 \mathrm{~m}$ & 10 & $5.8 \%$ & $100 \%$ & $7.1 \%$ & $12.9 \%$ \\
$20 \mathrm{~m}$ & 9 & 8.7 & 100 & 10.1 & 18.8 \\
$30 \mathrm{~m}$ & 9 & 12.0 & 100 & 13.7 & 25.7 \\
$50 \mathrm{~m}$ & 4 & 16.0 & 100 & 18.0 & 34.0 \\
$100 \mathrm{~m}$ & 2 & 29.5 & 100 & 33.4 & 62.9 \\
\hline
\end{tabular}

The movement of the net during towing was depicted from recordings of the towing depth recorder. It was found that the movement of the net in seas having a simple profile of temperature gradient against depth was less than that of seas having a drastic thermocline (Fig. 9.).

\section{Discussion}

It was observed that similar tendency prevailed in sample of fish larvae and filtration of water in surface towing at two areas differed mainly in the amount of plankton, i.e. difference of number of fish larvae taken and volume of water filtered caused by 

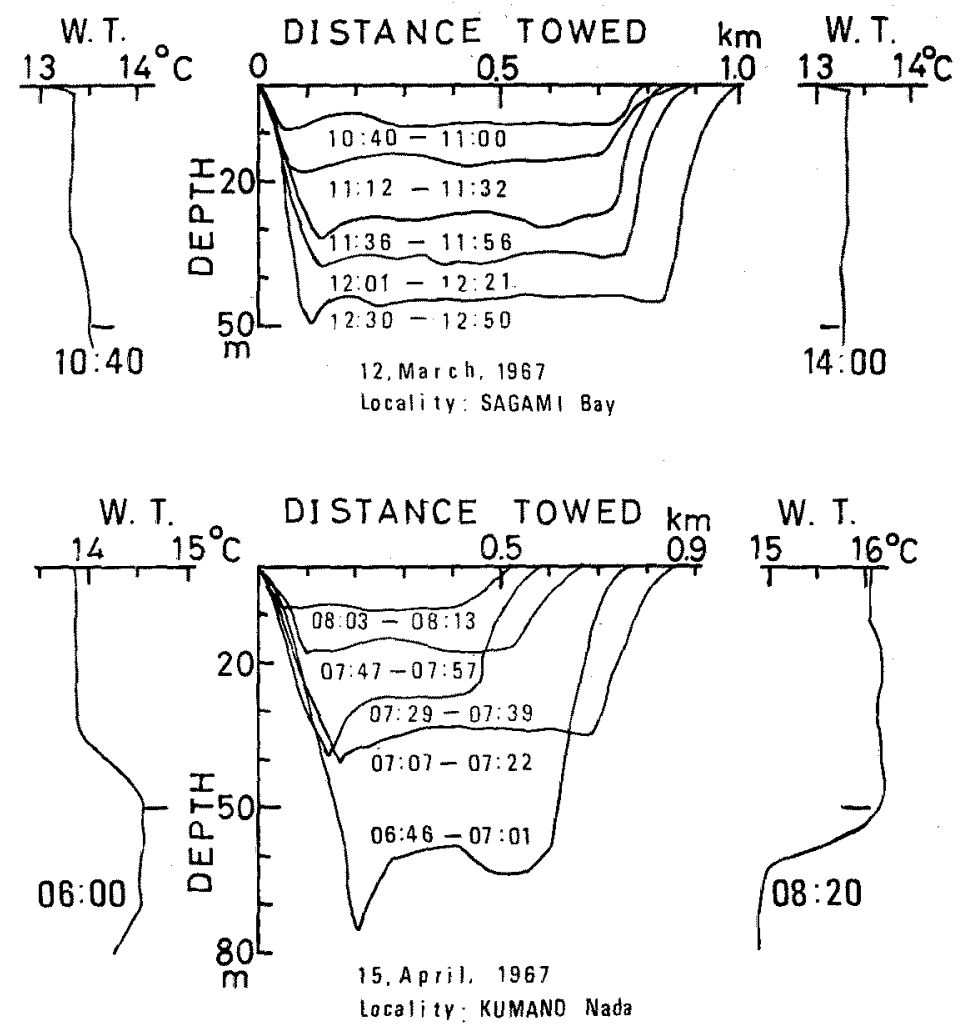

Fig. 9. Movement of net in towing and temperature profile with the depth.

mesh differential is significant in high sea area and it turns insignificant in coastal area and the difference caused by order of tow becomes large. This difference found in the two areas is considered to be caused by net clogging of small organisms. In general, they are rich in coastal area and poor in high sea area, so it is necessary to decrease the towing duration to eliminate the effect of net clogging, especially in coastal areas.

Remarkable differences among station have to be considered. In the coastal area all towings were carried out in a very restricted area and the 2 nd towings were operated immediately after the 1st towing, in conjunction with the turning of the ship's direction. On the contrary, in the high sea area each 2 nd towing was carried out after the 1st towing in the same ship direction and thus towings were carried out in a broad area. Moreover, the survey extended for 5 days in the latter case while in the coastal area the 10 paired tows were carried out in one day. So there were less difference in space and time in the former and vice versa in the latter. Nevertheless great difference among stations is observed in the towings of coastal areas. The most plausible reason is that in both areas the diurnal change in the amount of larvae would occur. However, in coastal area, the collection was much affected by the diurnal change of distribution of migratory larvae 
such as Engraulis japonica that was the dominant species in most seasons. The data have to be classified by sampling time of the day and by the region in further studies of sampling variation.

As for size composition, it is difficult to get representative samples using a single sampling gear because of mesh selectivity ${ }^{20)}$. The smaller individuals, in general, easily pass through the larger meshed net than that of the smaller. However, clogging of mesh aperture occurs easily in the smaller mesh. Larger or active larvae avoid the net at low towing speed but there exists some limitations in increase of towing speed because of the strength of nets ${ }^{22)}$. Comparing the size composition of collections by two nets, it seems that the larger meshed net $(1.0 \mathrm{~mm}$ mesh) is less effective in collecting smaller larvae of less than $5 \mathrm{~mm}$ total length (Fig. 8). Combination of two mesh kinds is commonly used for research of larval fishes. However, each mesh size has its own mesh selectivity as aforementioned, and it seems very difficult to analyze the data of catch in numbers and size composition using net that has two mesh sizes. And this inadequacy of combination of two meshes is also suggested by former workers ${ }^{18,20)}$. On the whole, it may be said that the larger meshed net is suitable for survey in coastal area for it's smaller variation of collection but the smaller mesh is not suitable due to mesh cloging.

It is desirable that any sample has a smaller confidence limit in respect to the mean. For comparing the collections by two different towings, both experimental error and towing variation ( $\sigma_{\text {error }}$ and $\left.\sigma_{\text {tow }}\right)$ must be considered. If it is assumed that these factors are independent of each other, then the conficence limit of a single towing observation at $95 \%$ level will be approximately:

$$
\mu \pm 2 \sqrt{\sigma^{2}+\sigma_{\text {tow }}^{2}} \ldots \ldots \ldots \text { (1) }
$$

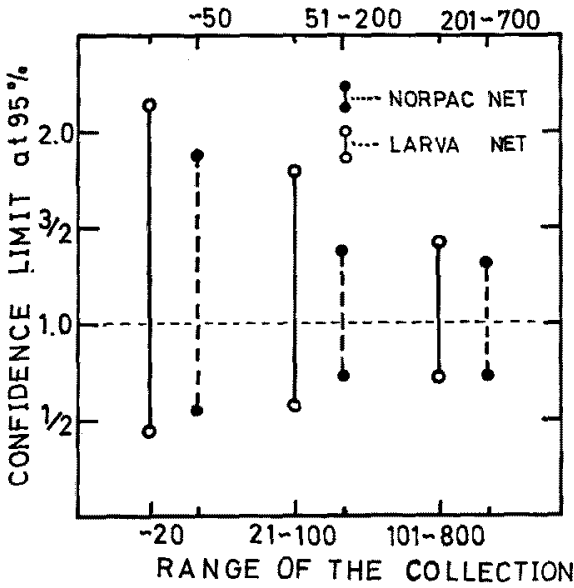

Fig. 10. Confidence limit of a single net tow observation expressed as the ratio to the mean value at $95 \%$ level against amount of larval fish taken. Range of the collection for Norpac net is shown at the top, larva net, below.

Calculating these values from the towing data of NORPAC net and $0.5 \mathrm{~mm}$ meshed larva net, the relative confidence limits expressed as the ratio of the above term to the mean value are shown in Fig. 10 against the amount of catch. It is evident from this figure that the more is the number of fish over 100 individuals per tow, the less is the confidence limit. The confidence limit of collection by the NORPAC net is always smaller 
than that of the larva net. It may be caused by the following reasons; (1) NORPAC nets were towed simultaneously at $20 \mathrm{~m}$ depth but larva net was towed singularly and the towing was repeated at surface, (2) Diurnal change in the distribution of larval fish was larger at surface layers than at subsurface layers ${ }^{14,23}$, (3) Individuals of more developed larvae were abundant at surface layers whereas larvae of earlier stages were abundant at subsurface layer ${ }^{23,24}$ and the latter were less active and brought smaller net avoidance.

Though the sampling methods employed are different by the authors, comparison of confidence limits reported by them is made and shown in Table 10. The upper limit lies approximately between $5 / 2$ and $3 / 2$ and the lower one lies between $1 / 3$ and $3 / 4$. Confidence limit of the present case are not so small as the previous workers at low amount of catch. However, they are fairly small at large catch. Generally, the oblique towing produces smaller sampling variation than the vertical towing ${ }^{8,10)}$ and it is assumed that the collection by the horizontal towing has larger sampling variation than that of the other methods of towing. However, the results of present case are not in accordance with this assumption excepting the case of collection of low amount.

Table 10. Comparison of confidence limit of a single net tow observation reported by some workers.

\begin{tabular}{|c|c|c|c|c|c|}
\hline $\begin{array}{l}\text { Confidence limit } \\
\text { at } 95 \% \text { level }\end{array}$ & $\begin{array}{l}\text { Range of } \\
\text { collection }\end{array}$ & $\begin{array}{c}\text { Object } \\
\text { organisms }\end{array}$ & $\begin{array}{l}\text { Towing } \\
\text { method }\end{array}$ & $\begin{array}{l}\text { Opening of } \\
\text { net month }\end{array}$ & Author \\
\hline $.70-1.40$ & $51-162$ & fish larvae & horizontal & $1.0 \mathrm{~m}^{2}$ & present author \\
\hline $.64-1.56$ & $?$ & anchovy egg & vertical & $.16 \mathrm{~m}^{2}$ & ITo \\
\hline $.58-1.71$ & $387-43300$ & copepods & oblique & $.44 \mathrm{~m}^{2}$ & WINSOR \& CLARKE \\
\hline $.58-1.72$ & $6-510$ & sardine egg & oblique & $2.0 \mathrm{~m}^{2}$ & SILLIMAN \\
\hline $.53-1.87$ & $32-2420$ & cope, Sagitta & vertical & $.16 \mathrm{~m}^{2}$ & MOTODA \& ANRAKU \\
\hline $.49-2.04$ & $?$ & copepods, etc & oblique & $.012 \mathrm{~m}^{2}$ & Barnes \& TRANTER \\
\hline $.45-2.22$ & $?$ & copepods, etc & vertical & $1.0 \mathrm{~m}^{2}$ & Barnes \& Tranter \\
\hline $.43-2.34$ & $166-1850$ & copepods & vertical & $.44 \mathrm{~m}^{2}$ & WINSOR \& ClaRKE \\
\hline $.37-2.66$ & $?$ & anchovy larvae & vertical & $.16 \mathrm{~m}^{2}$ & Iто \\
\hline $.70-1.43$ & $102-761$ & fish larvae & horizontal & $1.0 \mathrm{~m}^{2}$ & present author \\
\hline $.56-1.79$ & $24-98$ & fish larvae & horizontal & $1.0 \mathrm{~m}^{2}$ & present author \\
\hline $.46-2.16$ & $7-18$ & fish larvae & horizontal & $1.0 \mathrm{~m}^{2}$ & present author \\
\hline
\end{tabular}

From these facts above mentioned the amount of collection has to be set more than 50 individuals per tow to reduce the effects of small number variation ${ }^{14}$ and the effects of both net avoidance and non-uniform distribution ${ }^{11)}$ of larvae.

The standardization of sampling methods other than the above is needed for future analysis of larvae research.

Furthermore, the movement of net at subsurface towing and volume of water filtered are taken for consideration. In most cases it was observed that the net ascended just after the point of wire out. After this initial ascent, the oscillation of net occurred. 
The range of the initial ascent and the following oscillation varied from time to time. In most cases larger oscillation was observed at deeper layers towing and at the sea having obvious thermocline. However, it is not clear whether large oscillation of net is caused directly by the difference of water masses or by other physical factors.

Up to one fourth of contaminant of water volume was recorded in both descent and in ascent in horizontal towing in the depth of more than $30 \mathrm{~m}$. This contamination will be decreased with the prolongation of horizontal towing duration, but it has some limitations due to the occurrence of net clogging in extended filtration. It is known that most of the pelagic fish larvae are dominant in the upper several tens of meters, generally, less than $30 \mathrm{~m}$ deep ${ }^{14,23,24}$. From these facts it seems difficult to know the precise nature of vertical distribution of each fish species using these nets without any opening and closing apparatus. Thus there exists some limitations in the horizontal net towings of subsurface layers. In this respect the method of oblique towing is remarkable in its simplicity of operation and its certaintly of collection by eliminating the vertical migration of fish larvae ${ }^{15,21)}$. And this point will be also discussed in the following paper.

\section{Acknowledgement}

The author wishes to express his appreciation to Professor Dr. Y. NosE, faculty of Agriculture of the University of Tokyo, for his kind guidance and to Drs. S. TANAKA, T. KUSAKA and T. IsHII, the Ocean Research Institute of the University of Tokyo, providing the direction and offering the facilities for field surveys. $\mathrm{He}$ is also grateful to Dr. M. SHImizu and other staff of Laboratory of Fisheries Biology, Faculty of Agriculture, the University of Tokyo, for their kind help and encouragement throughout this work.

\section{References}

1) W. Aron, E. H. Ahlstrom, B. McK. Bary, A. W. H. Be and W. D. Clarke: Limnol. Oceanogr., 10 (3), 330-340 (1965).

2) Y. Alzawa, R. Marumo and M. Omori: Inform. Bull. Planktol. Japan, (12), $60-66$ (1965).

3) S. Nishizawa and M. ANRaku: Bull. Fac. Fish. Hokkaido Univ., 6 (4), 298-309 (1956).

4) S. Motoda, M. Anraku and T. Minoda: ibid., 8 (1), 1-22 (1957).

5) S. Ito and S. Nishimura: Ann. Rept. Japan Sea Reg. Fish. Lab., (4), 57-64 (1958)

6) D. J. Tranter and A. C. Heron: Aust. Jour. Mar. Freshwat. Res., 18, 89-111 (1967).

7) D. J. Tranter and P. E. SMath: Review on Oceanographic Methodology 2, 27-56 UNESCO (1968).

8) H. Barnes and D. J. Tranter: Austr. Jour. Mar. Freshwat. Res., 16 (3), 293-306 (1965).

9) C. P. WInsor and L. A. WALford: Jour. Cons., 11 (1), 190-204 (1936).

10) C. P. Winsor and G. L. Clarke: Jour. Mar. Res., 3 (1), 1-34 (1940).

11) H. Barnes and S. M. Marshall: Jour. Mar. Biol. Assoc., 30 (2), 233-263 (1951).

12) S. Motoda and M. Anraku: Bull. Fac. Fish. Hokkaido Univ., 6 (2), 152-175 (1955). 
13) S. Ito: Ann. Rept. Japan Sea Reg. Fish. Lab., (4), 33-41 (1958),

14) R. P. Silliman: Jour. Mar. Res., 5 (2), 118-130 (1943).

15) J. P. BRIDGer: Jour. Cons., 22 (1), 42-57 (1956).

16) A. Fleminger and R. I. Clutter: Limnol. Oceanogr., 10 (1), 96-104 (1965).

17) R. P. Silliman: Jour. Mar. Res., 6 (1), 74-83 (1946).

18) M. Anraku, M. Azeta and S. Kimura: Inform. Bull. Planktol, Japan, (14), $50-54$ (1967).

19) D. J. Tranter, J. D. Kerr and A. C. Heron: Aust. Jour. Mar. Freshwat. Res., 19: (1), 65-75 (1968).

20) E. H. Ahlstrom et al: Recommended interim procedures for measurements in biological oceanography, Nat. Acad. Sci. U.S.A., 23 pp (1964).

21) M. ANRAKu and M. Azeta: Inform. Bull. Planktol. Japan, (13), 34-40 (1966).

22) R. A. BARkley: Jour. Cons., 29 (2), 146-157 (1963).

23) H. IDA: This Bull., 38, 981-994 (1972).

24) E. H. AнLsтrom: Fish Bull. U.S. Fish Wildlife Serv., (161) 107-146 (1960). 